\title{
KEBIJAKAN DIVIDEN DAN VOLATILITAS HARGA SAHAM DI BURSA EFEK INDONESIA
}

\author{
SUTANDIJO \\ Universitas Pamulang \\ *Email : dosen01892@unpam.ac.id
}

\begin{abstract}
This study objective is to explore the impact of dividend policy (that are dividend payout ratio and dividend yield) on the investment risks reflected by the stock price volatility for the Indonesia capital market (IDX). Following to the study of Baskin (1989), the multiple least squares regression model is used in this paper. Also, following Baskin (1989), other four independent variables namely firm size, asset growth, leverage and earnings volatility added to the model. The sample of data is comprised of 64 public firms in the Kompas 100 Index for 5 consecutive years from 2012 to 2016 of which are listed on the Indonesia Stock Exchange (IDX). The results indicate that the dividend yield and the dividend payout ratio do not have significant influence to the stock price volatility In addition, firm size is negatively related to the stock price volatility and it has a statistically significant relationship. The result also indicate earnings volatility positively has influence to the stock price volatility. But, as for leverage and asset growth the results are not statistically significant. As for a conclusion, the dividend policy of the firms listed in Indonesia Stock Exchange (IDX) is not effective to influence the stocks' risks or affect investors' investment decisions. It seems that that firms needs a more stable and consistent dividend policy to effectively influence the stock price volatility in Indonesia Stock Exchange (IDX).
\end{abstract}

Keywords : dividend policy, dividend yield, dividend payout ratio, share price volatility, firm size, leverage, earnings volatility, asset growth, Baskin.

\section{PENDAHULUAN}

Menurut Bhattacharyya (2007), menjelaskan kebijakan dividen sudah menjadi suatu dari tantangan yang terberat bagi para ahli ekonomi keuangan. Black (1976) menyatakan bahwa dividen adalah merupakan suatu puzzle dengan potongan-potongan yang tidak sesuai satu sama lain (Bhattacharyya, 2007). Adalah sulit untuk menjawab secara eksplisit mengapa perusahaan membayar dividen dan mengapa investor memperhatikan dividen. Analisisanalisis yang menjelaskan kedua pertanyaan tersebut tidak cocok satu sama lain.

Salah satu teori tentang dividen yang paling klasik dan kontroversial adalah 
teori irelevansi dividen. Miller dan Modigliani (1961) pernah mengatakan bahwa kebijakan dividen tidak mempunyai relevansi terhadap nilai ekuitas perusahaan di bawah kondisi pasar modal yang efisien. Sebaliknya, the bird-in-hand theory mengatakan bahwa kebijakan dividen relevan, atau berpengaruh, terhadap nilai saham. Menurut teori tersebut, penerimaan dividen tunai adalah wujud dari kepastian yang akan mengurangi risiko untuk investor (Gordon,1959, 1963 ; Lintner ,1963 dan Walter, 1963).

Salah satu penelitian yang terkemuka mengenai relevansi atau irelevansi kebijakan dividen adalah penelitian yang dilakukan oleh Baskin (1989). Penelitian Baskin (1989) dilakukan guna menjelaskan dampak dari kebijakan dividen atas volatilitas harga saham. Adapun variabel atau proksi kebijakan dividen yang dipakai dalam studi yang dilakukan oleh Baskin (1989) tersebut yaitu dividend payout ratio dan dividend yield. Selain kedua variabel yang terkait dengan kebijakan dividen penelitian ini juga memasukkan beberapa variabel independen tambahan yaitu pertumbuhan aset (growth), ukuran perusahaan (size), tingkat utang (leverage) dan volatilitas laba.

Dari penelitian yang dilakukan Baskin (1989) disimpulkan bahwa kebijakan dividen dapat digunakan untuk mengendalikan volatilitas harga saham. Di samping itu variabel ukuran perusahaan ternyata juga berpengaruh negatif atas variabilitas harga saham, sedangkan pertumbuhan aset, tingkat utang, dan volatilitas laba mempunyai pengaruh positif atas variabilitas nilai saham.

Penelitian berdasarkan model Baskin (1989) ini bertujuan untuk mengetahui relevansi kebijakan dividen terhadap risiko investasi di pasar saham lokal. Walaupun sudah ada sejumlah penelitian mengenai relevansi kebijakan dividen di Indonesia namun sepanjang pengetahuan peneliti, penelitian yang dipublikasikan yang secara khusus meneliti dampak kebijakan dividen terhadap variabilitas nilai saham yang serupa dengan penelitian Baskin (1989) masih jarang dilakukan di Indonesia.

Terkait dengan risiko investasi atau volatilitas harga di pasar saham Indonesia yang relatif sangat tinggi (Tim Studi Bapepam-LK, 2011) implikasi dari penelitian ini menjadi cukup penting bagi pihak otoritas dan regulator pasar saham di Indonesia. Hasil penelitian ini dapat menjadi pertimbangan otoritas pasar saham dalam membuat regulasi yang tepat berkaitan dengan dividen. Bagi manajemen relevansi kebijakan dividen digunakan sebagai pertimbangan dalam mengatur kebijakan dividen agar nilai saham mendekati tingkat yang optimal. Bagi para investor penelitian ini berguna untuk menetapkan tingkat risiko investasi.

Penelitian menggunakan data 64 perusahaan terdaftar di Bursa Efek Indonesia (BEI) yang ada dalam Indeks Kompas100. Indeks Kompas100 dipilih sebagai sampel karena merepresentasikan perusahaan-perusahaan yang paling berkualitas di BEI, terutama dalam aspek likuiditas, kinerja dan nilai kapitalisasi. 


\section{KAJIAN TEORI}

\section{Pengertian Dividen}

Pengertian dividen biasanya mengacu kepada uang tunai yang dibayarkan yang berasal dari laba (Ross et al., 2013). Jika pembayaran yang dilakukan berasal dari sumber-sumber selain laba sekarang atau laba ditahan, biasanya istilah distribusi yang digunakan, bukan dividen. Dividen yang paling umum di Indonesia adalah dividen tunai regular (Gumanti, 2013)

\section{Kebijakan dividen}

Kebijakan dividen menurut Ross et.al (2013) adalah suatu pola dari waktu pembayaran dividen (the time pattern of dividend payout). Yaitu penentuan mengenai tingkat porsi laba yang didistribusikan kepada pemegang saham sebagai dividen sekarang, dan porsi laba yang ditahan guna diinvestasikan kembali. Menurut Gumanti (2013) dividen yang dibayarkan oleh perusahaan biasanya diukur dengan memakai dua macam parameter yaitu dividend payout ratio (DPR) dan dividend yield.

\section{Teori Kebijakan dividen}

1. Teori Ketidakrelevanan Dividen

Teori ini beranggapan bahwa harga saham tidak berhubungan dengan kebijakan dividen. Serupa yang diuraikan oleh Brigham dan Ehrhardt (2011) bahwa jika kebijakan dividen dianggap tidak mempunyai pengaruh signifikan terhadap baik harga saham maupun biaya modal maka kebijakan tersebut dengan sendirinya tidak relevan.

Penggagas utama teori tersebut yaitu Merton Miller dan Franco Modigliani (1961). Mereka menyatakan kalau nilai dari suatu perusahaan ditentukan semata-mata oleh kemampuannya menghasilkan keuntungan, atau kebijakan investasinya, dan risiko bisnisnya. Karena itu kebijakan dividen perusahaan bagi investor adalah tidak mempunyai perbedaan, atau tidak relevan.

2. Bird-in-hand theory

John Lintner (1962) dan Myron Gordon (1963) mendukung teori bahwa laba yang dibagikan sebagai dividen sekarang sifatnya lebih pasti daripada laba yang ditahan atau ditunda untuk dibagikan sebagai dividen. Teori ini dijuluki sebagai teori bird-in-hand, yang beranggapan bahwa bagi investor pendapatan dividen lebih bernilai dibandingkan dengan laba ditahan.

Menurut teori tersebut, capital gain yang terealisasi dalam bentuk dividen (diistilahkan sebagai bird-in-hand) lebih disukai daripada capital gain dalam bentuk laba ditahan yang belum terealisasi (diibaratkan sebagai burung di pepohonan atau di semak-semak). Burung di pepohonan atau di semak-semak dapat terbang setiap waktu, dan karena itu mengandung unsur 
ketidakpastian atau risiko. Dengan demikian maka teori ini mengatakan kalau dividen berpengaruh atau mempunyai relevansi terhadap harga saham.

\section{Teori Keagenan dan Hipotesis Arus Kas Bebas}

Sehubungan dengan pemisahan kepemilikan dan kendali atas perusahaan, teori Keagenan mengatakan bahwa dividen menolong mengurangi biaya keagenan (Jensen, 1986 ; Easterbrook, 1984). Pemisahan kepemilikan menyebabkan Information assymetry yaitu keunggulan manajemen dalam mengakses informasi dibandingkan dengan investor. Kesenjangan tersebut dapat menyebabkan adanya risiko bagi investor bahwa manajer akan menggunakan keunggulan itu untuk memaksimalkan kesejahteraannya sendiri dengan membebankannya kepada investor.

Menurut Jensen (1986), berdasarkan kerangka prinsipal-agen, dividen dipakai oleh pemegang saham sebagai sarana untuk mengendalikan investasi yang berlebihan yang dilakukan oleh manajer. Pengendalian perusahaan oleh manajer memungkinkan mereka menginvestasikan dana dalam proyek-proyek yang tidak menguntungkan perusahaan namun menguntungkan manajer. Dividen mengurangi aliran kas bebas ini sehingga mengurangi kemungkinan pemborosan.

Menurut Easterbrook (1984) dividen digunakan untuk mengambil kas bebas dari tangan manajer sehingga manajer akan harus mencari pendanaan bagi proyek-proyek baru dari pasar modal. Pendekatan manajer kepada pasar modal akan membuat pendisiplinan kepada manajer, melalui para analis keuangan, manajer investasi atau bank sehingga mengurangi biaya monitoring terhadap manajer.

\section{Durasi Investasi dan Risiko}

Dalam literatur keuangan dikenal istilah duration yang mengukur umur hidup ekonomis suatu investasi. Durasi suatu sekuritas dapat juga dianggap sebagai ukuran sensitivitas harga sekuritas terhadap perubahan yield atau interest rate (Hartono, 2009). Semakin panjang jangka waktu suatu obligasi atau investasi maka semakin besar risiko perubahan harga yang disebabkan oleh perubahan interest rate atau semakin volatil. Dividen pada saham seperti pembayaran bunga pada obligasi, merupakan pengembalian sebagian dari uang investor yang berakibat mengurangi durasi investasi.

\section{Volatilitas Harga Saham}

Variabilitas nilai saham mencerminkan fluktuasi pergerakan harga saham. Karena itu, secara umum, volatilitas harga di pasar saham menggambarkan tingkat risiko ketidakpastian investasi yang dihadapi oleh investor. Menurut Brigham \& Ehrhardt (2011) harga saham volatil karena investor merasa tidak pasti mengenai masa depan, terutama mengenai masa depan dari laba perusahaan.

Ukuran, Volatilitas Laba, Utang, dan Pertumbuhan

1. Ukuran perusahaan (Size) 
Variabel ukuran perusahaan (size) umumnya diukur sebagai logaritma natural dari total nilai pasar saham atau total nilai aset (Hartono, 2009). Nishat \& Irfan (2004) menyatakan bahwa perusahaan-perusahan kecil lebih mungkin untuk kurang terdiversifikasi dalam aktivitas mereka dan kurang menjadi sasaran penyelidikan yang seksama dari investor. Menurut Elton \& Grubber (1994) dalam Hartono (2009) perusahaan besar dipandang mempunyai kemampuan yang lebih besar dalam mengakses pasar modal, dengan demikian mereka memiliki beta yang lebih kecil.

2. Volatilitas Laba (Earnings Volatility)

Volatilitas laba didefinisikan sebagai tingkat variabilitas laba (Hartono, 2009). Volatilitas laba yang tinggi menyebabkan ketidakpastian karena menyebabkan kinerja perusahaan di masa depan sukar untuk diprediksi. Dengan demikian menurut Hartono (2009) volatilitas dari laba dipandang sebagai risiko perusahaan karena itu variabel ini mempunyai hubungan yang positif dengan risiko.

3. Tingkat Utang Perusahaan (Leverage)

Tingkat utang (leverage) diartikan sebagai rasio antara nilai buku total utang jangka panjang dengan nilai buku total aset (Hartono, 2009). Brigham \& Ehrhardt (2005) menyatakan bahwa penggunaan utang atau leverage meningkatkan risiko bisnis yang ditanggung oleh pemegang saham.

4. Tingkat Pertumbuhan Aset (Growth)

Variabel pertumbuhan aset dimaknai sebagai perubahan (tingkat pertumbuhan) total aset per tahun (Hartono, 2009). Nishat dan Irfan (2004) menyatakan bahwa kebijakan dividen dapat secara negatif terhubung dengan pertumbuhan dan kesempatan investasi. Perusahaan yang berada dalam tahap bertumbuh (growth stage) mempunyai kecenderungan untuk menahan labanya guna melakukan investasi di masa depan sehingga hal tersebut meningkatkan risiko.

\section{Penelitian Kebijakan Dividen Terdahulu}

Penelitian yang paling terkemuka yang meneliti pengaruh kebijakan dividen dilakukan oleh Baskin (1989). Penelitian-penelitian serupa selanjutnya di beberapa negara menunjukkan adanya pengaruh signifikan kebijakan dividen terhadap volatilitas harga seperti ditunjukkan oleh tabel penelitian terdahulu pada Lampiran A. yaitu antara lain Baskin (1989, Amerika Serikat), Allen \& Rachim (1996, Australia), Nishat \& Irfan (2004, Pakistan), Hussainey et al. (2011, Inggris), Hashemijoo et al. (2012, Malaysia), Song (2012, Kanada), Profilet \& Bacon (2013, Amerika Serikat), Ramadan (2013, Jordania), Sew et al. (2015, Malaysia), Shah \& Noreen (2016, Pakistan), dan Zainudin et al. (2018, Malaysia).

Penelitian serupa di negara-negara lain yang menunjukkan kebijakan dividen tidak efektif dalam mengurangi volatilitas harga saham antara lain Rashid \& Rahman (2008, Bangladesh), Ilaboya \& Aggreh (2013, Nigeria), dan Jahfer \& Mulafara (2016, Sri Lanka)

Hasil penelitian mengenai kebijakan dividen yang dilakukan oleh DeAngelo dan DeAngelo (1990) menunjukkan bahwa perusahaan-perusahaan yang mengalami kesulitan keuangan cenderung mengurangi dividen secara 
agresif ; hal ini menunjukkan bahwa dividen bisa merupakan indikator kondisi keuangan perusahaan dan karena itu berhubungan dengan risiko bagi investor.

Jiraporn dan Ning (2006) membuktikan bahwa perusahaan dengan tatakelola perusahaan yang kurang baik atau yang hak-hak pemegang sahamnya lemah membutuhkan dividend payout yang lebih besar. Dengan demikian dapat diartikan bahwa dividen adalah pengganti bagi tata kelola perusahaan yang kurang baik (substitusi), karena dividen dianggap mengurangi risiko. Penelitian Adjaoud and Ben-Amar (2010) membuktikan perusahaan yang memiliki tata kelola perusahaan bagus (good corporate governance) memberikan dividen payout ratio yang lebih tinggi. Penelitian tersebut juga menunjukkan adanya hubungan negatif antara risiko perusahaan dan dividend payout.

Bukti empiris lain yang mendukung hipotesis kas bebas yang menyatakan bahwa kebijakan dividen mengurangi risiko bagi investor juga dikemukakan oleh Caskey dan Hanlon (2013). Penelitian mereka membuktikan bahwa dividen dapat mengurangi kecurangan akuntansi dan dengan demikian, dividen mengindikasikan kualitas dari laba yang dilaporkan.

\section{Perumusan Hipotesis}

Berdasarkan uraian tinjauan pustaka dan rerangka pemikiran tersebut kemudian peneliti merumuskan enam hipotesis penelitian sebagai berikut :

H1 : Dividend Payout Ratio berdampak terhadap volatilitas harga saham (negatif).

$\mathrm{H}_{2}$ : Dividend Yield berdampak terhadap volatilitas harga saham (negatif).

H3 : Ukuran perusahaan berdampak terhadap volatilitas harga saham (negatif).

$\mathrm{H}_{4}$ : Pertumbuhan aset berdampak terhadap volatilitas harga saham (positif).

H5 : Tingkat utang berdampak terhadap volatilitas harga (positif).

H6 : Volatilitas laba berdampak terhadap volatilitas harga saham (positif).

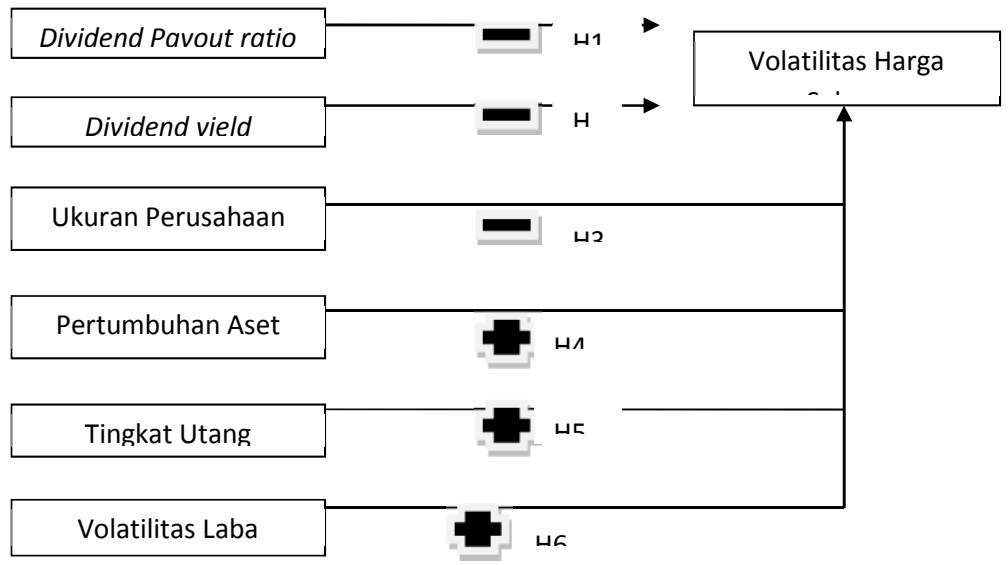

Gambar 1 : Rerangka Pemikiran dan Hipotesis 


\section{METODE PENELITIAN}

Berdasarkan tujuannya penelitian ini merupakan penelitian dasar (basic research). Di samping itu penelitian ini merupakan penelitian yang mempunyai tujuan untuk melakukan pengujian terhadap hipotesis yang dibangun berdasarkan pada teori-teori yang ada. Terkait dengan pengujian hipotesis tersebut tipe penelitian atau studi ini termasuk dalam jenis penelitian kausal yang menguji sebab akibat antara variabel independen dan variabel terikat.

\section{Operasionalisasi Variabel}

Penelitian ini akan memakai satu (1) variabel terikat (volatilitas harga saham) dan enam (6) variabel independen (dividend payout ratio, dividend yield, ukuran, pertumbuhan, tingkat utang dan volatilitas laba).

\section{Variabel Terikat}

Variabel terikat atau variabel dependen adalah variabel yang dipengaruhi atau dijelaskan oleh variabel bebas atau variabel independen (Sekaran, 2009). Variabel terikat untuk penelitian ini yaitu Volatilitas Harga Saham (Share Price Volatility) yang merupakan proksi dari risiko investasi dan yang dilambangkan dengan PriceVol.

Variabel dependen volatilitas harga saham (PriceVol) diukur dengan dengan menghitung deviasi standar dari perubahan harga saham selama periode yang diteliti. PriceVol diukur dengan memakai metode yang serupa dengan penelitian referensi, yaitu metode yang digunakan dalam penelitian Baskin (1989) .

$$
\text { PriceVol }=\sqrt[2]{\frac{\sum_{i=1}^{n}\left(\left(H_{i}-L_{i}\right) /\left(\frac{H_{i}+L_{i}}{2}\right)\right)^{2}}{n}}
$$

Keterangan :

$\begin{array}{ll}\text { PriceVol } & =\text { Volatilitas Harga Saham (Share Price Volatility) } \\ \mathrm{Hi} & =\text { Harga Saham Biasa Tertinggi untuk tahun } \mathrm{i} \\ \mathrm{Li} & =\text { Harga Saham Biasa Terendah untuk tahun } \mathrm{i} \\ \mathrm{n} & =\text { jumlah tahun sampel data } \\ \mathrm{i} & =\text { tahun penelitian }\end{array}$

\section{Variabel Independen}

Variabel bebas atau variabel independen adalah variabel yang menolong menjelaskan varian dalam variabel dependen (Sekaran, 2009). Variabel bebas 
yang digunakan untuk penelitian ini adalah Dividend Payout Ratio (DPR), Dividend Yield, Size, Growth, Debt dan Earnings Volatility.

1. Dividend Payout Ratio (DPR)

Variabel ini pada hakekatnya menyatakan berapa porsi laba bersih perusahaan yang didistribusikan sebagai dividen kepada investor. Dengan kata lain, variabel ini mencerminkan kemampuan perusahaan dalam memelihara tingkat pembayaran dividen. Variabel ini merupakan rasio antara dividen dengan laba bersih perusahaan.

Variabel ini diukur melalui perbandingan antara total kumulatif dividen yang dibayarkan kepada pemegang saham dan total kumulatif laba bersih perusahaan untuk semua tahun yang diteliti.

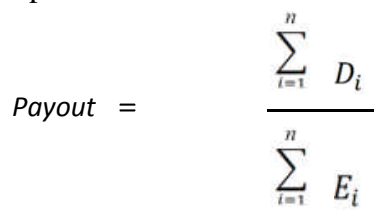

2. Dividend Yield

Variabel ini diukur dengan cara membagi jumlah total dividen yang didistribusikan kepada pemegang saham dengan rata-rata nilai pasar dari saham tersebut pada tahun yang bersangkutan.

$$
\text { Yield }=\sum_{i=1}^{\mathrm{n}} \frac{D_{i} / M V_{i}}{\mathrm{n}}
$$

3. Ukuran Perusahaan (Size)

Size merupakan ukuran dari nilai pasar perusahaan. Variabel ukuran (size) diukur sebagai logaritma natural dari nilai pasar saham biasa (Hartono, 2009).

$$
\text { Size of the Firm }=\quad \ln \left(\sum_{i=1}^{n} \frac{M V_{i}}{n}\right)
$$

4. Volatilitas Laba Perusahaan (Earnings Volatility)

Earnings Volatility adalah mengukur tingkat stabilitas atau konsistensi dari rasio laba operasi perusahaan (Earnings before interest and after taxes = EBIT) terhadap aset dari tahun ke tahun. Variabel ini diukur dengan menghitung standard deviation atas rasio EBIT terhadap aset. 


$$
\text { Earnings Volatility }=\sqrt[2]{\frac{\sum_{i=1}^{n}\left(R_{i}-\bar{R}\right)^{2}}{n}}
$$

5. Tingkat Utang (Leverage)

Tingkat utang perusahaan atau leverage terkait dengan solvabilitas. Solvabilitas adalah ukuran kapabilitas perusahaan dalam membayar utangutangnya. Leverage merupakan nilai buku total utang jangka panjang dibagi dengan nilai buku total aset (Hartono, 2009). Variabel ini diukur dengan rasio dari semua long term debt terhadap total aset.

6. Tingkat Pertumbuhan (Growth)

Variabel pertumbuhan merupakan perubahan (tingkat pertumbuhan) tahunan dari aset total perusahaan (Hartono, 2009).

$$
\text { Growth }=\frac{\sum_{i=1}^{n}\left(\frac{\Delta \text { Asset }_{i}}{\text { Asset }_{i}}\right)}{n}
$$

\section{HASIL ANALISIS DAN PEMBAHASAN}

\section{Uji Asumsi Klasik}

\section{Uji Normalitas}

Uji normalitas yang dipakai untuk penelitian ini merupakan analisis statistik berupa uji non-parametik Kolmogrov-Smirnov (K-S). Hasil uji statistik Kolmogorov-Smirnov (Lampiran B) menunjukkan angka KolmogorovSmirnov $Z$ adalah 1,137 dan tidak signifikan pada 0,05 (karena $\mathrm{p}=0.151>0,05)$. Hal tersebut membuktikan bahwa residual terdistribusi secara normal.

\section{Uji Multikolinieritas}

Ada tidaknya multikolinearitas dalam penelitian ini dideteksi dengan menggunakan nilai tolerance dan variance inflation factor (VIF). Berdasarkan hasil yang diperoleh, (dapat dilihat dalam Lampiran B), tabel collinearity statistics mengindikasikan semua variabel independen memiliki nilai tolerance $>0,10$ dan nilai VIF $<10$. Oleh karena itu bisa dikatakan jika model persamaan regresi yang digunakan tidak mempunyai masalah multikolinieritas.

\section{Uji Autokorelasi}

Untuk mendeteksi keberadaan Autokorelasi dalam model regresi dilakukan test Durbin-Watson (DW test). Dalam persamaan regresi $(\mathrm{N}=64, \mathrm{k}=6)$ nilai $\mathrm{dL}=1,400$, nilai $\mathrm{dU}=1,800$ sedangkan $4-\mathrm{dU}=2,200$. Nilai Durbin Watson 
(Lampiran B) adalah sebesar 2,024. Dengan demikian model persamaan regresi lolos dari uji autokorelasi karena memenuhi kriteria nilai DW berada di antara nilai $\mathrm{dU}=1,800$ dan nilai 4-dU $=2,200$.

\section{Uji Heteroskedastisitas}

Uji heterokedastisitas dalam studi ini dilakukan dengan Uji Park dan Uji Glejser. Uji Park dan Uji Glejser dengan menggunakan SPSS menunjukkan hasil bahwa mayoritas nilai probabilitas variabel-variabel bebas pada model tersebut lebih besar dari $\alpha=5 \%$ (lihat Lampiran B). Hasil uji tersebut mengindikasikan bahwa model yang digunakan penelitian ini relatif bebas dari heteroskedastisitas.

\section{Analisis Hasil Regresi}

Tabel 1

Analisis Hasil Regresi

\begin{tabular}{|l|c|c|c|c|}
\hline \multicolumn{1}{|c|}{ Variable } & Hypothesis & Coefisien & $t$-Statistics & $p$ value \\
\hline Constant & & & & \\
\hline Yield & & 385,641 & 8,433 & 0,000 \\
\hline Payout & $(-)$ & 2,219 & 1,394 & 0,169 \\
\hline Size & $(-)$ & $-0,039$ & -0.379 & 0,706 \\
\hline Growth & $(+)$ & $-10,402$ & $-7,293$ & $0,000 * *$ \\
\hline Lev & $(+)$ & 0,039 & 0.207 & 0,837 \\
\hline Evol & $(+)$ & 1,921 & 3.815 & 0,105 \\
\hline Dependent Variable & Pvol & & $0,000 * *$ \\
\hline N & 64 & & \\
\hline Adjusted R & 0,593 & & \\
\hline F-statistic & 16,277 & & \\
\hline p value & $0.000 * *$ & & \\
\hline $\begin{array}{l}* \\
*\end{array}$ Signifikan pada $\alpha=0,1$ & & & \\
\hline
\end{tabular}

(Sumber : Data diolah dengan SPSS).

PVol=volatilitas harga saham, Yield $=$ dividend yield, Payout $=$ dividend payout ratio, Size $=\log \mathrm{n}$ ukuran perusahaan, Growth $=$ tingkat pertumbuhan aset, Lev=tingkat utang jangka panjang terhadap aset, EVol=volatilitas EBIT

Angka adjusted $R$ square pada tabel 1 sebesar 0,593 pada persamaan regresi menunjukkan bahwa keseluruhan variabel dalam penelitian ini hanya dapat menjelaskan variasi perubahan volatilitas harga sebesar 59\%, sedangkan selebihnya dijelaskan oleh variabel selain dari variabel penelitian.

Dari output hasil regresi pada tabel 1 nilai probabilitas signifikansi persamaan regresi sebesar 0,000 . Hal ini menunjukkan bahwa model persamaan 
regresi tersebut adalah cocok atau fit dalam menganalisis dampak variabelvariabel independen atas variabel terikat $P$ Vol.

Output SPSS dari model regresi pada tabel 1 mengindikasikan jika variabel bebas Yield berpengaruh positif namun tidak signifikan terhadap variabel terikat PVol. Namun di sisi lain Payout berpengaruh negatif dan tidak signifikan. Hasil regresi juga menunjukkan bahwa, tidak sesuai dengan prediksi, variabel bebas Growth dan Lev mempunyai positif tetapi tidak signifikan atas variabel terikat PVol. Variabel bebas yang lain yaitu Size dan Evol masing-masing mempunyai koefisien bertanda negatif dan positif, hal ini sesuai dengan prediksi, pengaruh mereka terhadap $P V o l$ dinyatakan signifikan.

\section{SIMPULAN DAN SARAN}

Kebijakan dividen pada umunya tidak efektif dalam mempengaruhi volatilitas harga saham di Bursa Efek Indonesia. Kesimpulan tersebut bertentangan dengan hasil penelitian serupa terutama di negara-negara yang mempunyai pasar saham yang sudah mapan atau maju.

Bahwa hasil penelitian menunjukkan kebijakan dividen yang diwakili oleh dividend payout ratio dan dividen yield tidak berhubungan dengan volatilitas harga saham mengindikasikan bahwa kondisi pasar saham di Indonesia berbeda dengan di negara-negara lain yang sudah lebih mapan dan maju. Di negaranegara yang mempunyai pasar saham yang telah maju terdapat banyak perusahaan yang telah mencapai tahap mature, sedangkan di negara-negara dengan pasar saham yang belum begitu berkembang pada umumnya lebih banyak terdapat perusahaan-perusahaan yang masih dalam tahap bertumbuh. Perusahaanperusahaan yang telah mature pada umumnya membagikan dividen dalam proporsi yang relatif tinggi terhadap laba. Di samping itu mereka secara konsisten berusaha mempertahankan tingkat dividend payout ratio. Sedangkan perusahaan-perusahaan yang belum mature atau masih dalam tahap pertumbuhan cenderung tidak konsisten dan tidak stabil dalam mendistribusikan dividen, atau bahkan tidak pernah membagikan dividen sama sekali.

Dari data yang dikumpulkan terlihat bahwa pada umumnya perusahaanperusahaan Kompas100 yang menjadi sampel penelitian ini tidak konsisten dalam membagikan dividen, dimana perusahaan-perusahaan tersebut kadang membagikan dividen, dan kadang tidak. Hanya 27 dari 64 (42\%) perusahaan yang secara konsisten membagikan dividen secara berturut-turut paling tidak dalam jangka waktu 4 tahun. Dari 27 perusahaan tersebut hanya beberapa perusahaan yang secara konsisten mempertahankan tingkat payout ratio.

Inkonsistensi dalam pembayaran dividen dari perusahaan-perusahaan 
yang diteliti menunjukkan kebijakan dividen yang lemah. Investor tidak bisa memastikan apakah suatu perusahaan yang membagikan dividen tahun ini akan membagikan dividen lagi tahun depan, dan berapa? Karena itu tingkat dividen tidak lagi dianggap sebagai suatu sinyal yang diperhitungkan oleh investor. Investor baru akan memperhitungkan tingkat dividen sebagai faktor yang mengurangi risiko jika perusahaan menetapkan kebijakan dividen yang stabil dan konsisten.

Implikasi dari aspek metode penelitian, penelitian ini menggunakan metode regresi OLS (Ordinary Least Square) yang bisa menjadi bias hasilnya manakala terdapat faktor multikolinieritas yang relatif tinggi. Penelitianpenelitian selanjutnya dengan metode yang lebih disempurnakan sangat dibutuhkan untuk memastikan bahwa kebijakan dividen efektif (atau tidak efektif) dalam menurunkan tingkat volatilitas harga saham.

Terdapat beberapa saran yang dapat diajukan sehubungan dengan hasil penelitian ini untuk penelitian-penelitian yang serupa di masa depan :

1. Model penelitian mengenai hubungan antara kebijakan dividen dan risiko investasi bisa diperkaya dan diperluas dengan meneliti aspek-aspek lain atau variabel-variabel yang terkait, misalnya manajemen laba, corporate social responsibility, good corporate governance, ownership, likuiditas saham, dan sebagainya.

2. Data observasi diperbanyak jumlahnya dan periode yang diteliti diperpanjang, tetapi tetap hanya menggunakan perusahaan-perusahaan yang berkualitas tinggi dan memiliki likuiditas tinggi.

3. Penelitian memasukkan variabel dummy sektor industri atau ownership.

4. Penelitian selanjutnya menggunakan metode regresi yang lebih canggih seperti misalnya metode regresi ridge untuk menghindari adanya hasil yang bias atau kurang kuat karena adanya masalah multikolinieritas (Sekaran, 2009).

\section{DAFTAR PUSTAKA}

Adjaoud, F. \& Ben-Amar, W. (2010). Corporate Governance and Dividend Policy : Share Holder's Potection or Expropriation? Journal of Business Finance and Accounting, 37 (5) \& (6), 648-667.

Allen, D. E., \& Rachim, V. S. (1996). Dividend policy and stock price volatility: Australian evidence. Applied Financial Economics, , 6(2), 175-188.

Baskin, J. (1989). Dividend Policy and the Volatility of Common Stocks. The Journal of Portfolio Management, 15 (3), 19-25. 
Bhattacharyya, N. (2007). Dividend Policy : A Review. Managerial Finance, 33 (1), 4-13.

Brigham, Eugene F \& Ehrhardt, Michael C. (2011). Financial Management : Theory and Practice. $13^{\text {th }}$ ed. South-Western : Cengage Learning.

Caskey, J. \& Hanlon, M. (2013). Dividend Policy at Firms Accused of Accounting Fraud. Contemporary Accounting Research, 30 (2), 818-850.

DeAngelo, H. \& DeAngelo, L. (1990). Dividend Policy and Financial Distress : An Empirical Investigation of Troubled NYSE Firms. The Journal of Finance, 505 (5), 1415-1431.

Ghozali, Imam A. (2011). Aplikasi Analisis Multivariate dengan Program SPSS. Semarang : Badan Penerbit Universitas Diponegoro.

Gumanti, T. A. (2013). Kebijakan Dividen : Teori, Empiris, dan Implikasi. Yogyakarta : UPP STIM YKPN.

Hashemijoo, M., Ardekani, A. M. \& Younesi, N. (2012). The Impact of Dividend Policy on Share Market Price Volatility in the Malaysian Stock Market. Journal of Business Studies Quarterly, 4 (1), 111-129.

Hussainey, K., Mgbame, C.O., Chijoke-Mgbame, A. M. (2011). Dividend Policy and Share Price Volatility: UK evidence. Journal of Risk Finance, 12 (1), 57-68.

Ilaboya, O. J. \& Aggreh, M. (2013). Dividend Policy and Share Price Volatility. J. Asian Dev. Stud., 2 (2), 109-122.

Jahfer, A. \& Mulafara, A. H. M. A. (2016). Dividend Policy and Share Price Volatility : Evidence from Colombo stock market. International Journal of Managerial and Financial Accounting, 8 (2), 97-108.

Jiraporn, P. \& Ning, Y. (2006). Dividend Policy, Shareholder Rights, and Corporate Governance. Journal of Applied Finance, 16 (2), 24-36.

Hartono, J. (2009). Teori Portofolio dan Analisis Investasi. Yogyakarta : BPFE.

Nishat, M. \& Irfan C. M. (2004). Dividend Policy and Stock Price Volatility in Pakistan. (Doctoral dissertation, University of Karachi, Pakistan).

Profilet, K. A. \& Bacon, F. W. (2013). Dividend Policy and Stock Price Volatility in the US Equity Capital Market. Journal of Business and Behavioral Sciences, 25 (2), 63-72.

Ramadan, I. Z. (2013). Dividend Policy and Price Volatility : Empirical Evidence from Jordan. International Journal of Academic Research in Accounting, Finance and Management Sciences, 3 (2), 15-22.

Rashid, A. \& Rahman, A. Z. M. A. (2008). Dividend Policy and Stock Price Volatility : Evidence from Bangladesh. Journal of Applied Business and Economics, 7 (1), 1-12.

Ross, Stepehen A., Westerfield, Randolph W. \& Bradford, Jordan D. (2013). Fundamental of Corporate Finance. 10th ed. New York : Irwin/McGraw Hill.

Sekaran, Uma \& Bougie, Roger. (2009). Research Methods for Business : a Skill Building Approach. 5th ed. Chichester : John Wiley and Sons.

Sew, Eng Hooi, Albaity, M., \& Ibrahimy, A. (2015). Dividend Policy and Share Price Volatility. Investment Management and Financial Innovations, 12(1) 226-234. 
Shah, Syed A. \& Noreen, Umara. (2016). Stock Price Volatility and Role of Dividend Policy : Empirical Evidence from Pakistan. International Journal of Economics and Financial Issues, 6(2) 461-472.

Song, Xiaoping. (2011). The Relationship between Dividend Policy and Stock Price Volatility - A Canadian Study. (A Research Project Submitted in Partial Fulfillment of the Requirements for the Degree of Master of Finance, Saint Mary's University, Canada).

Suliyanto. (2011). Ekonometrika Terapan : Teori dan Aplikasi dengan SPSS. $1^{\text {st }}$ ed. Yogyakarta : Penerbit ANDI.

Tim Studi Bapepam-LK. (2011). Volatilitas Pasar Modal Indonesia dan Perekonomian Dunia. Bapepam-LK.

Zainudin, Rozaimah, Mahdzan, N.S., Chee, Hong Yet. (2018). Dividend Policy and Stock Price Volatility of Indutrial Products Firms in Malaysia. International Journal of Emerging Markets, 13 (1) 203-217. 